\title{
Clinical aspects of ovarian pathology in the mare
}

\author{
Mats H. T. Troedsson', Patrick M. McCue'2 and Margo L. Macpherson' \\ Department of Large Animal Clinical Sciences, College of Veterinary Medicine, University of Florida, Gainesville' and Equine Reproduction Laboratory \\ College of Veterinary Medicine and Biomedical Sciences, Colorado State University ${ }^{2}$
}

\begin{abstract}
Summary
Equine ovarian abnormalities can be divided for clinical purposes into abnormalities of follicular development, ovulation abnormalities, luteal dysfunction, ovarian tumors, and miscellaneous abnormalities. The objective of this review is to discuss specific causes of ovarian pathologies within these groups, their effect on fertility, diagnostics, and treatment options. It is concluded that ovarian abnormalities is a common cause of subfertility and infertility in the mare. Mares with abnormalities of ovarian follicular development caused by gonadal dysgenesis, advanced age, and equine Cushing's disease are generally more difficult to treat compared to mares with persistent anovulatory follicles, persistent corpus luteum, luteal insufficiency, or ovarian tumors. Recent data on the effect on follicular development following subcutaneous implantation of slow release GnRH agonist deslorelin acetate is discussed. It is concluded that deslorelin acetate can cause temporary down-regulation of FSH secretion with associated prolonged inter-ovulatory intervals. Removal of the implant following ovulation may circumvent this side effect. The use of testosterone and inhibin assays to accurately diagnose mares with granulosa-theca cell tumors (GTCT) is discussed. a-Inhibin, but not dimeric inhibin is elevated in approximately $90 \%$ single blood samples from mares with GTCT. Daily fluctuations in serum testosterone, makes a single blood samples analysis of this hormone less predictable for the tumor.
\end{abstract}

Keywords: Ovarian disorders, mare, fertility, diagnosis, treatment

\section{Klinische Aspekte ovarieller Alterationen bei der Stute}

Für klinische Belange unterteilt man die Ovarialveränderungen der Stute in Entwicklungsstörungen der Follikel, Ovulationsstörungen, luteale Dysfunktionen, Ovartumoren und sonstige Veränderungen. Diese Übersicht beleuchtet die spezifischen Ursachen der genannten Ovarveränderungen, deren Folgen für die Fertiltiät, diagnostische und therapeutische Möglichkeiten. Grundsätzlich sind Ovarveränderungen eine häufige Ursache für Sub- und Infertilität der Stute. Stuten mit Entwicklungsstörungen der Follikel, beruhend auf gonadaler Dysgenesie, fortgeschrittenem Alter oder einer Cushing-Erkrankung sind im allgemeinen schwieriger zu behandeln als diejenigen Stuten mit persistierenden anovulatorischen Follikeln, persistierendem Corpus luteum, lutealer Insuffizienz oder Ovartumoren. Diskutiert werden neue Forschungsergebnisse über den Effekt von dem GnRH-Agonisten Deslorelin-Azetat, das, subkutan implantiert, langsam abgegeben wird, auf die Entwicklung des Follikels. Es wird festgestellt, dass Deslorelin-Azetat zu einer temporären Downregulation der FSH-Ausschüttung mit daraus resultierendem verlängertem interovulatorischen Intervall führen kann. Durch die Entfernung des Implantates nach der Ovulation kann dieser Nebeneffekt verhindert werden. Desweiteren wird der Einsatz von Testosteron- und Inhibin-Assays für die präzise Diagnose von Granulosazelltumoren bei der Stute diskutiert. Alpha-Inhibin, nicht jedoch dimerische Inhibine, sind in ungefähr $90 \%$ der einmalig gewonnenen Blutproben von Stuten mit Granulosazelltumoren erhöht. Die täglich schwankenden Testosteronkonzentrationen lassen diesen Parameter bei einmaliger Blutprobenanalyse als weniger geeignet für die Diagnose eines Tumors erscheinen.

Schlüsselwörter: Ovarveränderungen, Stute, Fertilitätsrelevanz, Diagnose, Behandlung

\section{Introduction}

The anatomy of the equine ovary differs from almost all other species. A typical mammalian ovary has a central medulla and a superficial cortex with germinal epithelium covering the ovarian surface. The cortex contains the follicles and oocytes, and ovulation can occur anywhere from the germinal epithelium. In the equine ovary, the medulla is superficial and the cortex is located in the interior of the ovary. The germinal surface epithelium of the cortex reaches the surface only at the ovulation fossa, and this is the only area from which ovulations occur. The unusual ovarian anatomy may explain some of the physiological and endocrine events that are characteristic for folliculogenesis and ovulation in horses. For example, a mature follicle has to "migrate" through the ovarian stroma towards the ovulation fossa before it can ovulate. This may explain the unusually long and variable estrus, and the specific periovulatory endocrine pattern that is characteristic to the mare.

Ovarian abnormalities and diseases may have a temporary or permanent effect on fertility. Pathological conditions of the equine ovary can be divided into 1) abnormalities of follicular development, 2) abnormalities of ovulation, 3) luteal dysfunction, 4) ovarian tumors, and 5) miscellaneous other abnormalities. A clinical evaluation of ovarian pathology should always start with a complete history of the mare's estrous cycles, behavior, and reproductive performance. Examination of the reproductive tract should include rectal palpation, transrectal ultrasonography and vaginoscopy. Size, location, and follicular and luteal activity of the ovaries should be evaluated. The presence of an ovary smaller than $20 \mathrm{~mm}$, or larger than $100 \mathrm{~mm}$ suggests an ovarian abnor- 
mality. Repeated examinations are useful to assess progressive changes in ovarian activity. The ovulation fossa should be palpable on normal ovaries. The absence of a palpable ovulation fossa suggests ovarian neoplasia. Peripheral blood hormonal profiles add important information to the examination.

\section{Abnormalities of Follicular Development}

\section{Chromosomal Abnormalities}

The normal chromosome number of the domestic horse (Equus caballus) is 64, and it consists of 62 autosomes and two sex chromosomes (Bowling 1996). The karyotype of the normal mare and stallion are $64, \mathrm{XX}$ and $64, \mathrm{XY}$, respectively. Abnormalities of the sex chromosomes have been associated with infertility in the horse, although these conditions are very rare. The most commonly reported chromosomal abnormalities of mares are 63, $X$ gonadal dysgenesis and 64, $X Y$ sex reversal (Bowling et al. 1987). With 63,X gonadal dysgenesis, only a single sex chromosome is present (Hughes et al. 1975). The condition occurs when the sex chromosome pair fails to separate during meiosis, producing one gamete without a sex chromosome and another with two sex chromosomes. The equine condition is analogous to Turner's syndrome in humans. In $64, X Y$ sex reversal, phenotypic sex does not match chromosomal sex. Two syndromes are possible with 64, XY sex reversal: $X Y$ gonadal dysgenesis or $X$-linked testicular feminization. $X Y$ gonadal dysgenesis is a $Y$-linked abnormality that results in a lack of testicular development and a subsequent lack of androgen synthesis. Testicular feminization is an X-linked abnormality where females develop testes that secrete androgens but targeted embryologic structures do not develop into male reproductive organs because they lack androgen receptors. (George and Wilson 1994).

The phenotypic characteristics in mares with chromosomal abnormalities are dictated by the type of syndrome a mare has (Bowling and Hughes 1993). Mares having 63,X gonadal dysgenesis develop as phenotypic females because of the absence of a $Y$ sex chromosome. Affected horses are often small in size for their age and breed, have small ovaries lacking follicular development, and have endometrial gland hypoplasia. The uterus and cervix are generally small and flaccid. The external genitalia are female, but the vulva may be smaller than normal and there is no clitoral hypertrophy. $\mathrm{XO}$ mares may exhibit anestrous or irregular estrous behavior and occasionally stand to be mated. True XO mares are considered to be sterile.

Mares with 64,XY gonadal dysgenesis have hypoplastic gonads (fibrous streaks or undifferentiated ovarian tissue) and a flaccid uterus and cervix, similar to $63, \mathrm{X}$ mares. Mares may not cycle or have normal estrous behavior. Mares with X-linked testicular feminization normally develop female external genitalia, an incomplete or absent uterus and cervix, a short, blind-ended vagina and abdominal or inguinal testes. Mares having $X$-linked testicular feminization may also exhibit stallion-like behavior.

Diagnosis of a chromosomal abnormality is based on physical examination findings and chromosome analysis or karyo- typing. Karyotyping can be performed on any tissue with actively dividing cells. A fresh blood sample should be collected into acid citrate dextrose or heparin, and sent by overnight courier to a laboratory specializing in animal karyotyping. No treatments are possible to correct a chromosomal abnormality.

\section{Age-Related Ovarian Dysfunction}

Ovarian dysfunction has been identified as a cause of subfertility in older ( $\Delta 20$ years) mares. Older mares may become infertile for several reasons related to the ovary: failure to cycle; failure to ovulate and failure to conceive due to aging oocytes.

Older mares frequently begin cycling later in the season than younger mares (Vanderwall et al. 1989). Older mares that cycle often have a longer follicular phase, and subsequently, a longer interovulatory interval (Vanderwall et al. 1989; Carnevale et al. 1993). Some aged mares develop large, anovulatory follicles. In one study, significantly more mares aged 16-20 years developed anovulatory follicles than mares aged 6-10 years (McCue and Squires 2002). Alternatively, older mares may have fewer follicles on their ovaries and elevated serum gonadotropins. It is postulated that mares with these reproductive characteristics frequently become reproductively senescent (Carnevale et al. 1994). Aged, senescent mares typically have small, inactive ovaries (follicles $£ 5 \mathrm{~mm}$ ) and a flaccid uterus and cervix. While senescent mares may still show behavioral signs of estrus, similar to anestrous or ovariectomized mares, ovarian function is completely absent.

No effective treatments are currently available for promoting follicular growth in senescent ovaries of mares. Gonadotropin releasing hormone ( $\mathrm{GnRH}$ ) has been used to stimulate follicular growth in mares with poor follicular development attributable to anestrous or transition. Several studies (reviewed Ginther 1992) have examined the effects of GnRH administered at different dosages and dosing intervals to stimulate follicular development in mares. In general, the number of mares responding to $\mathrm{GnRH}$ therapy increased as the size of follicle or time of year at the onset of therapy increased. In a recent study, use of human chorionic gonadotropin or deslorelin acetate (Ovuplantâ) did not enhance the ovulatory response of mares treated with native $\mathrm{GnRH}$ (Morehead et al. 2001). Similar studies have not been conducted with aged mares. An anecdotal report suggests that mares with senescent ovaries may respond to $\mathrm{GnRH}$ therapy if follicular size at the onset of therapy is $20 \mathrm{~mm}$ or greater. (R. Douglas, unpublished observations). Follicular activity, alone, may not be a good indication of ovarian function in aged mares.

Oocytes collected from aged donor mares, cultured and transferred to young recipient mares were less likely to result in pregnancy than oocytes from young donor mares (Carnevale and Ginther 1995). Furthermore, oocytes obtained from old mares and examined using transmission electron microscopy had more morphological abnormalities than oocytes from young mares (Carnevale et. al. 1999). Results from these studies suggest that oocyte quality declines as mares age, and this factor will contribute to poor fertility in older mares. 
Exogenous Hormone Treatment

Anabolic steroid administration may affect both estrous behavior and ovarian function. The treatment of mares with low doses of anabolic steroids can cause aggressive or stallionlike behavior, while high doses can inhibit ovarian activity and result in failure of follicular development and ovulation (Maher et al. 1983). Progestins are commonly given to cycling mares for the suppression of estrus or synchronization of ovulation. Mares may continue to ovulate during progestin administration, especially if treatment is started late in the luteal phase. A high incidence of persistent corpus luteum formation has been observed in mares that ovulate during progestin treatment (Daels et al. 1996).

Administration of the potent $\mathrm{GnRH}$ agonist deslorelin acetate (Ovuplantâ, Ft. Dodge) to induce ovulation has been associated with delayed follicular development and a prolonged interovulatory interval (Johnson et al. 2000, McCue et al. 2000). Deslorelin acetate is very effective in inducing ovulation, but treatment appears to cause a temporary down-regulation of FSH secretion. The low FSH concentrations have been associated with a prolonged period of decreased follicular growth. Administration of PGF2a at 7-8 days after ovulation appears to increase the risk of delayed follicular development. It has been suggested that PGF2a administration 'resets' the timing of the estrous cycle during a period when limited follicular activity is present. Removal of the deslorelin implant after ovulation has been detected, will decrease the incidence of prolonged interovulatory intervals (Fig. 1; McCue et al. 2002).

\section{Equine Cushing's Disease}

Mares with hypertrophy, hyperplasia, or adenoma formation in the pars intermedia of the pituitary (Equine Cushing's Disease, or ECD) have been reported to have abnormal estrous cycles, infertility, or both (Beech 1994, van der Kolk 1997). The mechanisms by which ECD cause reproductive abnormalities have not been determined. Potential cause(s) may be destruction of the gonadotrophs of the anterior pituitary due to compression by the enlarged pars intermedia (Daels and Hughes 1993) or suppression of gonadotropin secretion due to elevated levels of glucocorticoids or androgens produced by the adrenal cortex (Daels and Hughes 1993). In support of the glucocorticoid hypothesis, administration of dexamethasone to intact mares results in reduced estrous behavior, $\mathrm{LH}$ concentrations, follicular growth and incidence of ovulation (Asa and Ginther 1982). In addition, administration of dexamethasone to ovariectomized mares results in suppression of pituitary LH and FSH secretion (McNeill-Wiest et al. 1988), and treatment of pony mares with dexamethasone during the winter eliminates estrous behavior (Pope et al. 1995). A majority of horses diagnosed with ECD are older, with the average age being approximately 20 years. Consequently, the decrease in reproductive efficiency in mares with ECD may be partly due to advanced age.

Clinical signs of ECD include hirsutism and abnormal haircoat shedding patterns, polyuria, polydipsia, and hyperhidrosis (Fig. 2; Dybdal 1997). Diagnostic tests for ECD include measurements of serum glucose, insulin, adrenocorticotropic
Fig 1a-c Deseroline acetate (Ovuplant ${ }^{\circledR}$, Ft. Dodge) implanted into the vulva. Following local anesthetics (1a), the Ovuplant ${ }^{\circledR}$ is inserted into the vulva (1b), and removed after detection of ovulation (1c).

Deserolin-Azetat (Ovuplant ${ }^{\circledR}$, Ft. Dodge)-Implantation in die Vulva. Ovuplant ${ }^{\circledR}$ wird nach Lokalanästhesie (1a) in die Vulva eingesetzt und nach Feststellung der Ovulation (1c) wieder entfernt.

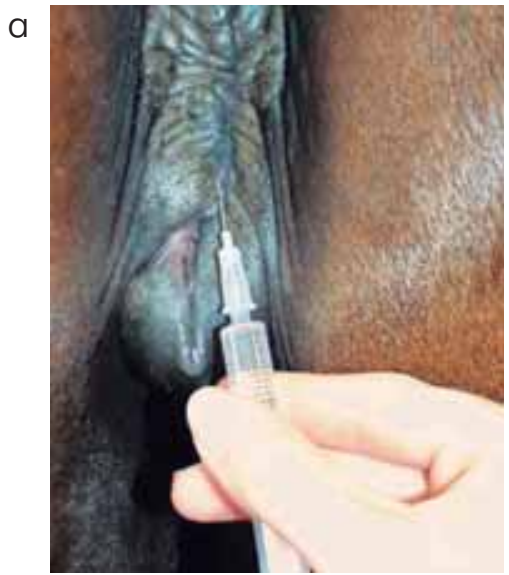

b

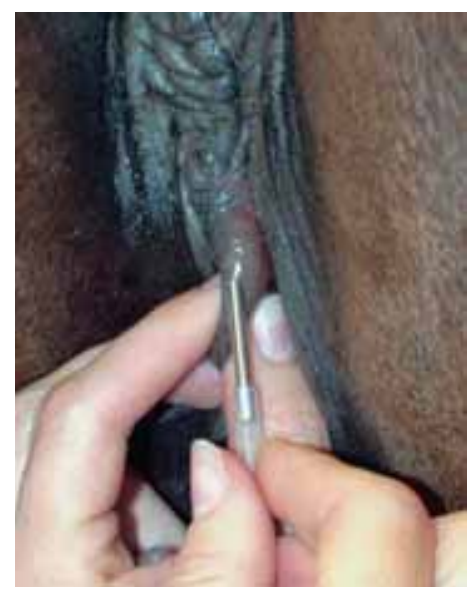

C

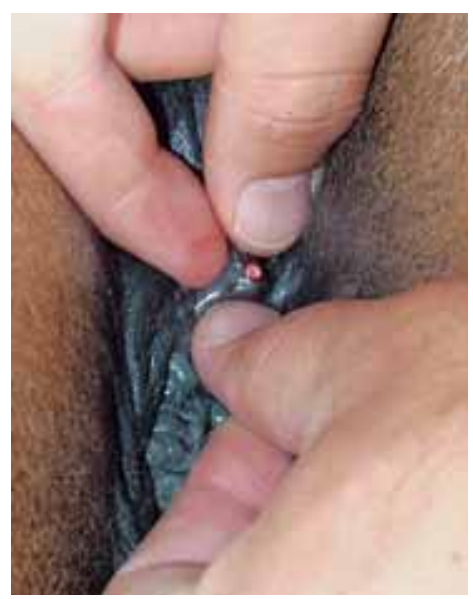

hormone (ACTH) cortisol levels, dexamethasone suppression, ACTH stimulation, and thyrotropin-releasing hormone response tests (McCue 2002). The measurement of single samples for basal cortisol or ACTH concentrations are of limited value in the diagnosis of ECD.

The medical management of ECD includes the administration of pergolide mesylate, a dopamine receptor agonist, at a 
dosage of 0.5-2 mg every 24 hours in an adult horse. The serotonin antagonist cyproheptadine, has also been used but it may not be as efficacious as pergolide. The dose of cyproheptadine is $0.25 \mathrm{mg} / \mathrm{kg}$ every 24 hours, given once in the morning.

Fig 2 Picture of a mare with Cushing's disease. Note the long curly hair coat.

Bild einer Stute mit Morbus Cushing. Beachten Sie das lange, lockige Haarkleid

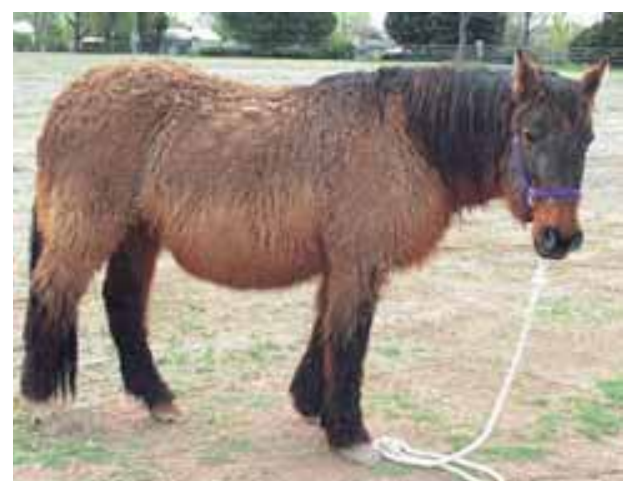

\section{Abnormalities of Ovulation}

Anovulatory Follicles

Ovulation failure is a normal physiologic event for the mare during the spring and fall transition periods, but it may also occur occasionally during the physiologic breeding season. Persistent anovulatory follicles (PAF) may be quite large (5-15 $\mathrm{cm}$ in diameter), persist for up to 2 months, and result in abnormal estrous behavior and prolonged interovulatory intervals (Meyers 1995). The cause of ovulation failure has been suggested to be endocrine in nature. Absence of sufficient pituitary gonadotropin stimulation to induce ovulation, or insufficient estrogen production from the follicle has been proposed as possible mechanisms. PAF were reported in a recent study, to occur in approximately $8.2 \%$ of estrous cycles (McCue and Squires 2002). The formation of an anovulatory follicle was preceded by development of normal endometrial folds or edema in $78.3 \%$ of these cases. Initial growth patterns of follicles destined to become anovulatory were usually normal and the first indication of a problem was the detection of echogenic particles within the follicular fluid. The incidence of PAF was also found to increase with age.

PAF may contain blood and have been termed hemorrhagic anovulatory follicles. The hemorrhage can be detected ultrasonically as scattered free-floating echogenic spots within the follicular fluid. The follicular fluid may form a gelatinous, hemorrhagic mass within the follicular lumen (Fig. 3). Ultrasonographically, these structures may contain echogenic fibrous bands traversing the follicular lumen. A thickening of the follicular wall may be observed in anovulatory follicles. This thickening is often associated with luteinization of the follicular wall, and $85.7 \%$ of PAF were found to be luteal structures based on elevations in plasma progesterone concentrations (McCue and Squires 2002).

The administration of prostaglandins may result in the destruction of the luteal cells in mares with luteinized PAF. A majority of non-luteinized PAF will spontaneously regress in 1 -
4 weeks. Treatment with human chorionic gonadotropin $(2,500$ IU, IV) or a GnRH-agonist (Ovuplantâ, 2.1 mg, SQ) to induce ovulation or luteinization of the anovulatory follicle is generally not effective. Pregnancy does not usually occur if a persistent follicle eventually spontaneously ovulates or is

Fig 3 Ultrasonographic image of an anovulatory hemorrhagic follicle in a mare. The follicle contains blood, which can be seen as free floating echogenic spots in the follicular fluid. Note the typical echogenic fibrous bands.

Ultrasonographisches Bild eines anovulatorischen hämorrhagischen Follikels bei einer Stute. Das im Follikel enthaltene Blut ist anhand der frei in der Follikelflüssigkeit flotierenden echogenen Spots erkennbar. Beachten Sie die typische echogene fibröse Septierung.

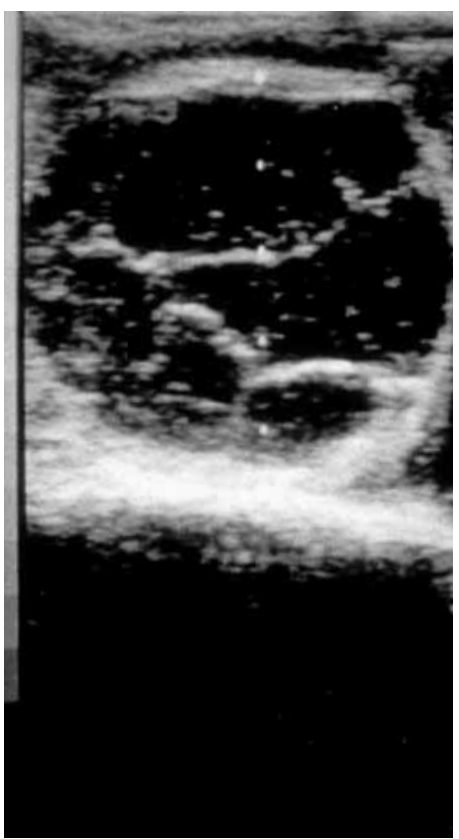

induced to ovulate. This is likely a result of degeneration of the oocyte over time. Pregnancy obviously will not occur if the follicle becomes hemorrhagic or luteinized without ovulating.

\section{Ovarian hematoma}

In the older literature, ovarian hematomas were reported to be one of the most common causes of unilateral ovarian enlargement (Meyers 1995, Bosu et al. 1982). Hematomas were noted to be a result of excessive hemorrhage into the follicular lumen following ovulation, or essentially greatly enlarged corpora hemorrhagica. The contralateral ovary was reported to be normal in size and function, and mares with this condition continued to cycle normally. No specific behavioral abnormalities were noted and endocrine patterns of the mare were normal. With the common use of ultrasound to closely monitor ovarian function, the occurrence of ovarian hematoma as a post-ovulatory structure should be reconsidered. It is the authors' opinions that most structures previously reported as ovarian hematomas most likely were hemorrhagic anovulatory follicles. Dramatic enlargement of a corpus hemorrhagicum following detection of a true ovulation is rare (if it ever happens). In contrast, formation of a blood filled follicular lumen in an anovulatory follicle is relatively common. 


\section{Abnormalities of Luteal Function}

Persistent Corpus Luteum

The corpus luteum (CL) is usually functional for 14-15 days after ovulation in non-pregnant mares, at which time luteolysis occurs as a result of PGF2a release from the endometrium. Although luteal cells appear to be sensitive to PGF2a almost immediately after ovulation, complete luteolysis and return to estrus in response to endogenous or exogenous PGF2a will not occur until five days after ovulation. Corpora lutea that fail to regress normally after ovulation are considered to be persistent (Stabenfeldt et al. 1974). The most common causes of a persistent corpus luteum are 1) ovulations late in diestrus, resulting in corpora lutea that are immature ( $<5$ days old) at the time of prostaglandin release; 2 ) embryonic loss after the time of maternal recognition of pregnancy; 3) pyometra, resulting in destruction of the endometrium and therefore diminished prostaglandin release, and 4) inadequate prostaglandin release at days 13-15.

If untreated, the corpus luteum may persist for 2-3 months. This syndrome may be suspected clinically in mares that are not expressing normal estrous behavior during the physiologic breeding season, and it must be differentiated from mares with silent heat. Diagnosis of a persistent corpus luteum is made by transrectal sonographic examination of the ovaries. The CL appears as a well-defined hyper-echoic structure on the ovary (Fig. 4). Mares with a persistent corpus luteum will

Fig 4 Ultrasonographic image of an active corpus luteum in a mare. The corpus luteum appears as a well defined hyper-echoic structure.

Ultrasonographisches Bild eines aktiven Corpus luteum bei einer Stute. Das Corpus luteum stellt sich als gut abgegrenzte hyperechogene Struktur dar.

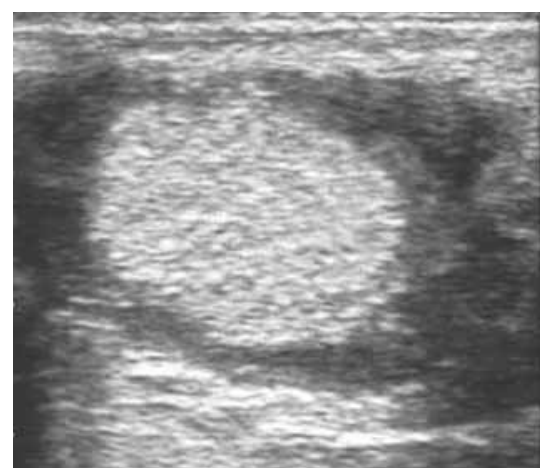

have good cervical and uterine tone on palpation, and the cervix will appear tight and dry on vaginal speculum examination because of the influence of progesterone. The diagnosis may be confirmed by analysis of plasma progesterone concentrations or a clinical response to prostaglandin administration. Progesterone concentrations $>1.0 \mathrm{ng} / \mathrm{ml}$ are indicative of the presence of active luteal tissue. A persistent corpus luteum will usually be eliminated by the administration of a single intramuscular dose of prostaglandins (PGF2a, 10 $\mathrm{mg}$; or cloprostenol, $250 \mathrm{mg}$ ).

\section{Shortened Luteal Phase (Premature Luteolysis)}

Premature ( $<15$ days) luteolysis is associated with an early onset of estrus and a decrease in the interovulatory interval. The most common cause of premature luteolysis in the mare is endometritis. Inflammation of the endometrium results in an acute activation of inflammatory mediators. One of these mediators is PGF2a, which in addition to its inflammatory effect also may cause luteolysis and return to estrus. Consequently, a mare that exhibits a shortened diestrus should be examined for endometritis. A culture, biopsy and cytologic examination of the uterus may be indicated.

\section{Luteal Insufficiency}

Primary luteal insufficiency implies a deficiency in progesterone production. Luteal insufficiency has been suggested to be a cause of subfertility in mares (Douglas et al. 1985). Maintenance of pregnancy in some habitually aborting mares following administration of exogenous progestogens offers circumstantial evidence that progesterone insufficiency may be responsible for some cases of pregnancy loss. However, data is limited and not supported by scientific evidence from controlled studies.

Luteal insufficiency secondary to PGF2a release in mares with endotoxemia has been reported (Daels et al. 1991), and should be considered in pregnant mares with gram-negative infection and/or endotoxemia-associated colic. Recent reports on the effect of exogenous administration of PGF2a during the periovulatory period suggest that PGF2a can delay the formation of a functional CL. Sub-optimal concentrations of progesterone were found in mares following treatment with PGF2a during the first 2 days after ovulation (Gunthle et al. 2000; Troedsson et al. 2001; Brendemuehl 2002; Nie et al. 2002). Although the CL eventually became functional and progesterone concentrations had returned to normal levels at day 14, pregnancy rates were significantly lower in treated mares (Troedsson et al. 2001; Brendemuehl 2002).

Minimum concentrations of progesterone required to maintain pregnancy in the mare has been suggested to be 2.0 $\mathrm{ng} / \mathrm{ml}$ (Daels et al. 1991). Repeated samples are necessary to diagnose luteal insufficiency since progesterone is released episodically. The most common treatment for luteal insufficiency is supplementation with the synthetic progestogen altrenogest (Regumate ${ }^{\hat{a}}$ ) at a dose of $0.044 \mathrm{mg} / \mathrm{kg}$, orally once daily. Options for duration of altrenogest supplementation include 1) treatment until day 60 of pregnancy or greater and measurement of endogenous progesterone level of $>$ $2.0 \mathrm{ng} / \mathrm{ml}$ (progesterone and altrenogest do not cross react on RIA), 2) treatment until day 120 of pregnancy, or 3) treatment until the end of gestation. It is important to emphasize the need to monitor fetal well-being when mares are kept on progestin supplementation to maintain pregnancy. A case of fetal mummification of a five-month old fetus in a pregnant mare at term has been reported (Barber and Troedsson 1996). The mare had been maintained on altrenogest throughout gestation.

\section{Ovarian Tumors}

Granulosa Cell Tumor (GCT)

The most common ovarian tumor in the mare is the granulosa cell tumor (Fig. 5; Hughes et al. 1980). Granulosa cell tumors are almost always unilateral, slow growing, and 
benign. Transrectal sonographic examination of the affected ovary often reveals a multicystic or honeycombed structure, but the tumor may also present as a solid mass or as a single large cyst. The contralateral ovary is usually small and inactive, although mares with a GCT on one ovary and a functional contralateral ovary have been reported (McCue et al. 1991). Behavioral abnormalities such as prolonged anestrus, aggressive or stallion-like behavior, and persistent estrus or nymphomania may be expressed in affected mares.

Fig 5 A surgically removed granulosa cell tumor. The ovary is greatly enlarged and multicystic.

Ein chirurgisch entfernter Granulosazelltumor. Das multizystische Ovar ist hochgradig vergrößert.

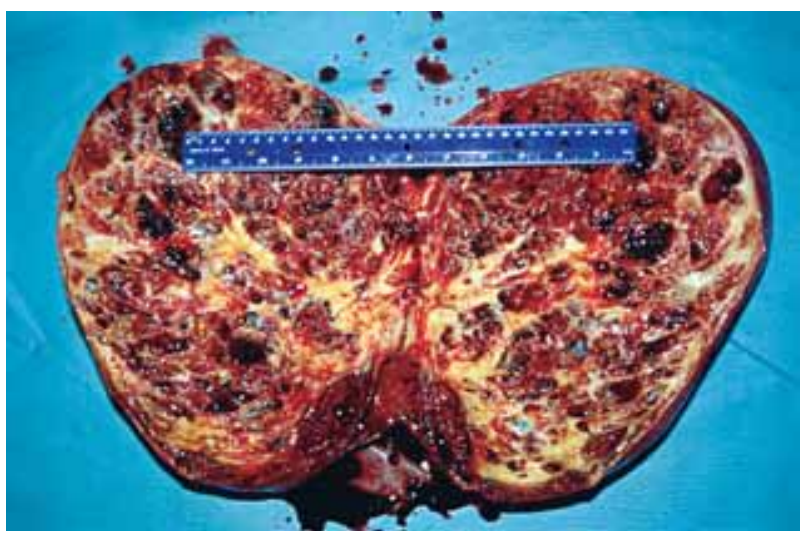

Granulosa cell tumors are hormonally active, and clinical diagnostic assays for the detection of a GCT include the measurement of inhibin, testosterone, and progesterone (Stabenfeldt and Hughes 1987, McCue 1992, Bailey et al. 2000). (a inhibin is elevated in approximately $90 \%$ of the mares with a GCT (McCue 1992, Bailey et al. 2002). It has been hypothesized that inhibin produced by the GCT is responsible for inactivity of the contra-lateral ovary, through the suppression of pituitary FSH release. However, recent reports on a poor correlation between dimeric inhibin and the presence of GCT raise questions with regards to the mechanism by which the contra-lateral ovary is suppressed in affected mares (Bailey et al. 2002, Watson et al. 2002). Serum testosterone in a single blood sample can be expected to be elevated in approximately $50-60 \%$ of affected mares. Daily fluctuations in testosterone concentrations have been reported, and repeated samples may have to be obtained during different days in order to detect elevated testosterone (Bailey et al. 2002). Progesterone concentrations in mares with a GCT are almost always below $1 \mathrm{ng} / \mathrm{ml}$, since normal follicular development, ovulation, and corpus luteum formation do not occur.

Granulosa cell tumors are usually surgically removed. Surgical approaches for tumor removal include colpotomy, flank and ventral midline laparotomy, and laparoscopy. Ovulation from the remaining ovary will occur approximately 6-8 months after tumor removal. Attempts at inducing follicular development and ovulation in the remaining ovary within 1 month after tumor removal by the administration of gonadotropin-releasing hormone ( $\mathrm{GnRH})$ has not been successful. However, the administration of equine follicle-stimulating hormone, in the form of equine pituitary extract, has been successful in inducing an ovulation from the contralateral ovary after the surgical removal of a GTC that resulted in a pregnancy.

\section{Cystadenoma}

The most common tumor of the surface epithelium of the equine ovary is the cystadenoma. The tumor occurs unilaterally, and the contralateral ovary is normal. The ultrasonographic appearance of the affected ovary may include one to many cyst-like structures. In general, these tumors are rare and benign and are not considered to be hormonally active, although mares with cystadenomas having elevated plasma testosterone concentrations have been reported (Hughes et al. 1980, Hinrichs et al. 1989).

The treatment of choice for an ovarian cystadenoma is surgical removal. The decision to remove the affected ovary does not have to be made immediately, as the tumor is slow growing and has not been reported to metastasize. However, if the tumor does continue to enlarge, the mare may exhibit episodes of abdominal pain.

\section{Teratoma and Dysgerminoma}

Teratomas and dysgerminomas are rare ovarian tumors of germ cell origin. Teratomas are considered to be benign, while dysgerminomas are potentially malignant. Both are unilateral, hormonally inactive, and associated with normal contralateral ovaries. Germ cell tumors may contain hair, bone, muscle, and other tissues. They do not alter the behavior of the mare and do not interrupt the estrous cycle. The treatment of choice for germ cell tumors is surgical removal. This is especially true for the dysgerminoma, because of its potential for metastasis.

\section{Literature}

Asa C. S. and Ginther O. J. (1982): Glucocorticoid suppression of oestrus, follicles, LH and ovulation in the mare. J Reprod Fert. (Suppl) 32, 247-251

Bowling A. T., Million L. and Hughes J. P. (1987): An update of chromosomal abnormalities in mares. J. Reprod. Fertil. Suppl., 35, 149-155

Bowling A. T. and Hughes J. P. (1993): Cytogenetic abnormalities. In: McKinnon A. and Voss J. (ed) Equine Reproduction. Philadelphia, Lea \& Febiger, 258-265

Bowling A. T. (1996): Horse genetics. Wallingford, Oxon, UK: CAB International, pp 115-122

Bailey M. T., Christman S. A., Wheaton J. E., Troedsson M. H. T., O'Brien T. D., Ababneh M. M. and Santschi E. M. (2000): Inhibin localization in equine granulosatheca cell tumors (GTCT) and dimeric inhibin concentrations and (inhibin forms in tumor fluid and plasma. J. Reprod. Fert. (Suppl) 56, 247-255

Bailey M. T., Wheaton J. E. and Troedsson M. H. T. (2002): Inhibin concentrations in mares with granulosa-thecal cell tumors. Theriogenology 57, 1885-1895

Barber J. A. and Troedsson M. H. T. (1996): A case of a mummified singleton fetus in a mare. J. Am. Vet. Med. Assoc. 9, 1438-1440

Beech (1994): J. Treatment of hypophysial adenomas. Comp Cont Educ Pract Vet 16, 921-923

Bosu W. T. K., Van Camp S. C., Miller R. B. and Owen R. R. (1982): Ovarian disorders: clinical and morphological observations in 30 mares. Can Vet J 23, 6-14 
Brendemuehl J. P. (2002): Effect of oxytocin and cloprostenol on luteal formation, function and pregnancy rates in mares. Theriogenology 58, 623-626

Carnevale E. M., Bergfelt D. R. and Ginther O. J. (1993): Aging effects on follicular activity and concentrations of FSH, LH, and progesterone in mares. Anim Reprod Sci 31, 287-299.

Carnevale E. M., Bergfelt D. R. and Ginther O. J. (1994): Follicular activity and concentrations of $\mathrm{FSH}$ and $\mathrm{LH}$ associated with senescence in mares. Anim Reprod Sci 35, 231-246

Carnevale E. M. and Ginther O. J. (1995): Defective oocytes as a cause of subfertility in old mares. Biol Reprod Mono 1, 209-214

Carnevale E. M., Uson M., Bozzola J. J., King S. S., Schmitt S. J. and Gates H. D. (1999): Comparison of oocytes from young and old mares with light and electron microscopy, Theriogenology 51, 299

Daels P. F., Stabenfeldt G. H., Hughes J. P., Odensvik K. and Kindahl $H$. (1991): Evaluation of progesterone deficiency as a cause of fetal death in mares with experimentally induced endotoxemia. Am. J. Vet. Res. 52, 282-288

Daels P. F. and Hughes J. P. (1993): The abnormal estrous cycle. In: McKinnon AO, JL Voss (eds). Equine Reproduction. Williams \& Wilkins, Baltimore. pp 144-160

Daels P. F., McCue P. M., DeMoraes M. and J. P. Hughes (1996): Persistence of the luteal phase following ovulation during altrenogest treatment in mares. Theriogenology 46, 799-81 1

Douglas R. H., Burns P. J. and Hershman L. (1985): Physiological and commercial parameters for producing progeny for subfertile mares by embryo transfer. Equine Vet J 3(suppl), 111-114

Dybdal N. (1997): Pituitary pars intermedia dysfunction (Equine Cushing's-like disease). In: Robinson N. E., ed. Current therapy in equine medicine, 4th ed. Philadelphia: Saunders. pp 499-501

George F. W. and Wilson J. D. (1994): Sex Determination and Differentiation. In: The Physiology of Reproduction, Second Edition. (Ed.) Knobil, E., Neill, J.D., New York, Raven Press, 3-28

Ginther O. J. (1992): Anovulatory season. In: Reproductive Biology of the Mare: Basic and Applied Aspects. Cross Plains, Equiservices, 166-170

Gunthle L. M., McCue P. M., Farquhar V. J. and Foglia R. A. (2000) Effect of prostaglandin administration postovulation on corpus luteum formation in the mare. In: Proc. Soc. Theriogenology. p139

Hinrichs K., Frazer G. S., de Gannes R. V. G., D. W. Richardson and R. M. Kenney (1989): Serous cystadenoma in a normally cyclic mare with high plasma testosterone values. J Am Vet Med Assoc 194, 381-382

Hughes P., Benirschke K., Kennedy P. C. and Trommershausen Smith A. (1975): Gonadal dysgenesis in the mare. J Reprod Fertil Suppl; 23, 385-390

Hughes J. P., Kennedy P.C. and Stabenfeldt G. H. (1980): Pathology of the ovary and ovarian disorders in the mare, In Proc. $9^{\text {th }}$ Int Cong Anim Reprod Artif Insem pp 203-222

Johnson C. A., Thompson Jr. D. L., Kulinski K. M. and Guitreau A. M. (2000): Prolonged interovulatory interval and hormonal changes in mares following use of Ovuplant ${ }^{\mathrm{T} M}$ to hasten ovulation. J Eq Vet Sci 20, 331-336

Maher J. M., Squires E. L., Voss J. L.and Shideler R. K. (1983): Effect of anabolic steroids on reproductive function of young mares. J Am Vet Med Assoc 183, 519-524

McCue P. M., LeBlanc M. M., Akita G. Y., Pascoe J. R., Witherspoon D. M. and Stabenfeldt G. H. (1991): Granulosa cell tumors in two cycling mares. J Equine Vet Sci 1 1, 281-282

McCue P. M. (1992): Equine granulose cell tumors, In Proc. 38th Annu Conv Am Assoc Equine Practnr pp 587-593
McCue P. M., Farquhar V. J. and Squires E. L. (2000): Effect of the $\mathrm{GnRH}$ agonist deslorelin acetate on pituitary function and follicular development in the mare. Amer Assoc Equine Pract pp 355356

McCue P. M., Niswender K. D. and Farquhar V. J. (2002): Induction of ovulation with deslorelin: options to facilitate implant removal. J Eq Vet Sci 22, 54-55

McCue P. M. and Squires E. L. (2002): Persistent anovulatory follicles in the mare. Theriogenology 58, 541-543

McCue P. M. (2002): Equine Cushing's Disease. Vet Clin Equine 18, 533-543

McNeill-Wiest D. R., Thompson D. L. and Wiest J. J. (1988): Gonadotropin secretion in ovariectomized pony mares treated with dexamethasone or progesterone and subsequently with dihydrotestosterone. Dom Anim Endo 5, 149-155

Meyers P. J. (1995): Ovary and oviduct. In: Kobluk C. N. and Ames T. R., Geor RJ, eds. The horse. Philadelphia: Saunders, pp 9991004

Morehead J. P., Colon J. L. and Blanchard T. L. (2001): Clinical experience with native $\mathrm{GnRH}$ therapy to hasten follicular development and first ovulation of the breeding season. J. Eq. Vet. Sci., 21 (2), 54-88

Nie G. J., Johnson K. E., Wenzel J. G. W. and Braden T. D. (2002): Effect of periovulatory ebolics on luteal function and fertility. Theriogenology 58, 461-463

Pope N. S., Sargent G. F. and Kesler D. J. (1995): The dexamethasone induced suppression of androgen secretions suppressed estrous behavior in pony mares during the winter. J Eq Vet Sci 15, 119-123

Stabenfeldt G. H., Hughes J. P., Evans J. W. and Neely D. P. (1974): Spontaneous prolongation of luteal activity in the mare. Equine Vet J 6, 158-163

Stabenfeldt G. H. and Hughes J. P. (1987): Clinical aspects of reproductive endocrinology in the horse. Compend Contin Educ 9, 678-684

Troedsson M. H. T., Ohlgren A. F., Ababneh M. M. and Gregas M. (2001): Effect of periovulatory prostaglandin F2a on pregancy rates and luteal function. Theriogenology 55, 1891-1899

Van der Kolk J. H. (1997): Equine Cushing's disease. Equine Vet Educ 9, 209-214

Vanderwall D. K., Peyrot L. M., Weber J. A. and Woods G. L. (1989): Reproductive efficiency of the aged mare, in Proceedings. Annu Meet Soc Therio pp 153-156

Watson E. D., Heald M., Tsigos A., Leask R., Steele M., Groome N. P. and Riley S. C. (2002): Plasma FSH, inhibin A and inhibin isoforms containing pro- and a $C$ in mares during winter anestrus, spring transition, and the breeding season. Reproduction 123, 535-542

Zhang T. Q., Buoen L. C., Weber A. and Ruth G. R. (1992): Variety of cytogenetic anomalies diagnosed in 240 infertile equine, in Proceedings. 12th Int Cong Anim Reprod Artif Insem pp 1939-1941

Zajac J. D. and Warne G. L.(1995): Disorders of sexual development. In Thakker R. V. (ed.): Balliere's Clinical Endocrinology and Metabolism. London, Balliere Tindall, 555-579

Prof. Dr. M. H. T. Troedsson

Department of Large Animal Sciences

University of Florida

P.O.Box 100136

Gainesville, FL 32610, USA

troedssonm@mail.vetmed.ufl.edu 